LAERE MIDDEL ODK

\title{
Spændinger mellem testdata og valg af læremidler. Et virksomheds- teoretisk perspektiv på læsevejledning i skolen
}

Af Karina Kiær,

UCSYD og DPU/Aarhus Universitet

Korrekt citering af denne artikel efter APA-systemet

(American Psychological Association System, 7th Edition):

Kiær, K. (2020). Spændinger mellem testdata og valg af

læremidler. Et virksomhedsteoretisk perspektiv på læsevejledning i skolen. Learning Tech - Tidsskrift for læremidler, didaktik og teknologi, (8), 94-121. DOI 10.7146/It.v5i8.119749 


\section{Abstract}

Denne artikel undersøger spændinger i forholdet mellem læsevejledning og undervisning belyst i forholdet mellem testdata og læremidler. Artiklen er en del af et igangværende ph.d.-projekt ${ }^{1}$, hvor jeg har skygget fire læsevejledere på tre forskellige skoler i to forskellige kommuner samt gennemført interviews af læsevejlederne og deres skoleledere. Data analyseres med udgangspunkt i den kulturhistoriske virksomhedsteori med særligt fokus på at belyse de spændinger, som er i virksomhedssystemet. På baggrund af analysen kan jeg konkludere, at læremidler foreslås, når testdata skal bruges i undervisningssituationer. Analysen viser, at læsevejlederens fagdidaktiske viden om både læseudvikling og staveudvikling er vigtig, når det handler om at understøtte lærerens hensigtsmæssige brug af læremidler i forhold til testdata. Undersøgelsen viser en tydelig spænding omkring forholdet mellem regler, arbejdsdeling og tid, fordi det har en betydning for fællesskaber (vejledning) på skolerne.

This article examines tensions between literacy coaching and teaching, especially between test data and learning materials. The article is part of an ongoing $\mathrm{PhD}$ project, where I shadow four literacy coaches at three different schools in two different municipalities, and conduct interviews with them and their school leaders. These empirical data are analyzed on the basis of the cultural historical activity theory with special focus on elucidating tensions. Based on the analysis, I conclude that learning materials are suggested when test data is to be used in teaching situations. The analysis shows that literacy coaches' subject didactic knowledge of both reading and spelling development is of great importance when it comes to supporting the teacher's intended use of learning materials in relation to test data. The research project presents a clear tension regarding the relationship between rules, division of labor and time, because it has an impact on coaching in schools. 


\section{Spændinger mellem testdata og valg af læremidler. Et virksomheds- teoretisk perspektiv på læsevejledning i skolen}

\section{Indledning}

I Danmark har der i de senere år været en diskussion om test i skolen, især nationale test. Nyere dansk forskning har peget på, hvordan de nationale test måler, målingernes troværdighed, og læreres og skolelederes brug, holdninger og viden i forhold til de nationale test er undersøgt. Det er kendetegnende, at lærere finder nationale test vanskelige at bruge, da de er for langt væk fra deres egen undervisningspraksis. Derfor kan de også kun fungere som et pædagogisk redskab i begrænset omfang (Bundsgaard \& Puck, 2016; Bundsgaard, 2018). Bundsgaard understreger, at der "findes ikke megen nordisk forskning, som undersøger potentialer for eller praksis med pædagogisk brug af test" (Bundsgaard, 2018, s. 6). Han peger især på potentialet $\mathrm{i}$ at bruge vejledningerne til testene eller læremidlerne, som relaterer sig til testen. Samtidig viser forskningen også, at lærere finder det vanskeligt at forstå testdata og bruge dem, især når det handler om deres undervisningsplanlægning (Datnow \& Hubbard, 2015; Young \& Kim, 2010). I reviewet af Nordenbo, Allerup, Andersen, Dolin, Korp, Larsen, Svendsen, Tiftikci, Wendt \& Østergaard (2009) tilskrives læreren, ikke overraskende og velargumenteret, en helt særlig rolle i forhold til den pædagogiske brug af test, men den internationale forskning har senere vist, at det at bruge testdata pædagogisk ${ }^{2}$ ikke er så lige til (Schildkamp Poortman, Luyten \&

2 Den engelske term vil være "instruction", og dermed ses det pædagogiske direkte i forbindelse med undervisning. 
Ebbeler, 2017). Rådgivningsgruppen i forhold til de nationale test anbefaler også at fremme det pædagogiske formål med test og knytte det tæt sammen med udvikling af skolens evalueringskultur. I den forbindelse er der et ønske om at "give lærere forbedrede vejledninger $i$ at tolke resultater og anvende dem sammen med andre evaluerings- og dokumentationsdata til at tilpasse undervisning og særlige indsatser til elevernes behov og potentialer" (UVM, 2020a, Anbefaling nr. 7, s. 10). En måde at gribe brugen an på pædagogisk har netop været ved at undervise og forberede eleverne på de opgavetyper, som har været i bl.a. de nationale test (Nordenbo et al. 2009, s. 31). Fænomenet kaldes teaching to the test, og det har da også været diskuteret i forskningslitteraturen i en årrække i flere lande (Sun, Przybylski \& Johnson, 2016). En anden måde at bruge test på pædagogisk kunne være, når testdata, læremidler og forskellige undervisningsmetoder forbindes med hinanden, fx også i vejledningssituationer sammen med en læsevejleder. Forskningen giver gode argumenter for at bruge testdata, da de kan bruges til at udvikle undervisning, øge undervisningskvaliteten og elevernes læring (Coburn \& Turner, 2011; Datnow \& Hubbard, 2015; Mandinach \& Gummer, 2013; Ikemoto \& Marsh, 2007; Schildkamp et al., 2017; Kiær, 2020). Det kræver altså mere end blot at have forskellige data til rådighed, det kræver også tid og mulighed for samarbejde (Coburn \& Turner, 2011). Eksempelvis nævnes professionelle læringsfællesskaber, når det handler om at bruge testdata, fordi der organisatorisk struktureres en mulighed for samarbejde og at have dialoger om data (Albrechtsen, 2016; Kiær, 2020). Vejledere ser ud til at have en meget betydningsfuld rolle, når det handler om at støtte læreres databrug (Huguet, Marsh \& Farrell, 2014; Marsh, Sloan McCombs \& Martorell, 2010; Mandinach \& Gummer, 2013). Schildkamp og kollegaer peger netop på betydningen af den pædagogiske og didaktiske viden, når det handler om at bruge data (Schildkamp et al., 2017, s. 253, Schildkamp \& Poortman, 2015, s. 13). Men i den danske forskning har vi meget begrænset viden om, hvilken betydning læsevejledning har, når det handler om at støtte lærere $\mathrm{i}$ brug af forskellige former for testdata. Næsten alle folkeskoler i Danmark har en læsevejleder, og forskning peger på, at læsevejledning kan have en afgørende rolle, når lærere skal bruge testdata til at udvikle undervisning. Læsevejledning kan altså føre til, at lærere forandrer deres praksis væsentligt og integrerer nye undervisningstilgange (Marsh, Bertrand \& Huguet, 2015; Marsh et al., 2010; Coburn \& Woulfin, 2012). Mausethagen, Skedsmo \& 
Prøitz (2016) peger på, at der er stor opmærksomhed omkring forskellige aktørers brug af testdata, fx lærere og skoleledere, og i mindre grad fokus på de iboende spændinger og hvordan de skaber muligheder og begrænsninger for udviklingsprocesser, fx hvor læremidler indgår i relation til testdata. Derfor foretager jeg også en analyse af disse spændinger. Spændinger er særligt interessante, fordi de ses som kilder til forandring og udvikling. De er historisk akkumulerede og ses både i og mellem virksomhedssystemer, og de kan være på flere niveauer, som jeg uddyber senere (Knutagård, 2013). Samtidig åbner spændinger op for muligheder og kalder på løsninger, der kan føre til transformationer i aktiviteter. Der kan bl.a. være tale om nogle strukturelle spændinger i og mellem virksomhedssystemer, men der kan også være tale om afvigelser fra fx regler. Spændinger kan også åbne op for det, der omtales som ineffektiviteter. Engeström og Sannino (2011) foreslår, at spændinger analyseres gennem artikulerede manifestationer; de kan altså genkendes, artikuleres, og de konstrueres til ord og handlinger. For blot at nævne et par eksempler, så oplever læsevejlederne en spænding mellem en test og et læremiddel, når testen viser en særlig fejltype, og når læremidlet bruges til træning inden for denne fejltype. Det kan også være, at regler om testning får betydning for læsevejlederens arbejde, så hun må anvende andre test $\mathrm{i}$ tiden, indtil den officielle ordblindetest kan tages.

Læremidler udgør en stor del af undervisningen i folkeskolen, og de kan betragtes som medierende artefakter mellem læreren og eleven. Der er tale om midler, som eleverne skal lære ved (Hansen \& Skovmand, 2011). Læremidler kan både være analoge og digitale, og der kan være tale om funktionelle læremidler, fx LST, mens andre læremidler har en indlejret didaktik (Hansen, 2010). Jeg rejser derfor følgende forskningsspørgsmål:

\section{Hvilke spændinger opstår, når læsevejledere skal vejlede lærere i brug af testdata i skolen set i relation til læremidler?}


I artiklen benytter jeg et bredt databegreb, som både indebærer test og formative data som fx elevopgaver fra klasserummet. Alle typer af test og andre formative data indgår i empirien, fordi de indgår som en del af skolens test- og vejledningsrutiner, og de omtales alle som test og data (Feldman, 2000; Hubers, Schildkamp, Poortman \& Pieters, 2017; Kiær \& Albrechtsen, 2020). Ved databrug forstår jeg her indsamling, analyse, fortolkning, intervention og evaluering af forskellige data, herunder også test (EVA, 2017; Lai \& Schildkamp, 2013). På baggrund af overstående vil jeg i denne artikel undersøge spændinger i forholdet mellem testdata og læremidler. Først vil jeg redegøre for min fremgangsmåde i forbindelse med indsamling af de empiriske data.

\section{Metode}

Det empiriske grundlag for at besvare forskningsspørgsmålet består af interviews af fire læsevejledere fra tre forskellige caseskoler i to forskellige kommuner, interviews af skoleledere samt observationsdata, der er indhentet ved brug af metoden skygning (McDonald \& Simpson, 2014; Czarniawska, 2008, 2014; Johnsson, 2014). Observationsmetoden er særlig velegnet til at følge efter centrale aktører, ting og processer i organisationer og se, hvordan de opfører sig og vedtages gennem interaktioner i forskellige hverdagssituationer (Vásquez, Brummans \& Groleau, 2012). "Shadowing entails a researcher closely following a subject over a period of time to investigate what people actually do in the course of their everyday lives, not what their roles dictate of them" (Quinlan, 2008, s. 1480). Metoden gør det muligt at følge læsevejlederen og testen som en skygge, mens de bevæger sig rundt i skolen. Jeg har skygget læsevejlederne i de rutiner, der er på skolen. Det drejer sig bl.a. om skole-/hjemsamtaler, hvor testresultater er indgået, læsevejlederens analyse af test, læsevejlederens teammøder med skolens andre læsevejledere eller ledelse, samt afholdte læsekonferencer, som kan ses som en form for vejledning og vejledningssituationer med lærere. Af etiske hensyn har jeg fravalgt testsituationer med elever, da forskning allerede viser, at nogle elever finder testsituationer udfordrende, og min tilstedeværelse kan måske forværre dette (Andreasen, 2019). Indtil nu, da undersøgelsen stadig pågår, er de empiriske data som følgende: 
Tabel 1.

Oversigt over data.

\begin{tabular}{|l|l|l|l|l} 
& $\begin{array}{l}\text { Interview } \\
\text { læsevejleder }\end{array}$ & $\begin{array}{l}\text { Skygning } \\
\text { læsevejleder }\end{array}$ & Situationer & $\begin{array}{l}\text { Interview } \\
\text { skoleleder }\end{array}$ \\
\hline Caseskole A & $\begin{array}{l}\text { Læsevejleder 1+2 } \\
\text { (LV1, LV2) } \\
156 \text { min. }\end{array}$ & $\begin{array}{l}\text { Læsevejleder 1+2 } \\
\text { (LV1, LV2) } \\
690 \text { min. }\end{array}$ & $\begin{array}{l}\text { Analyse } \\
\text { Teammøde } \\
\text { Vejledning } \\
\text { Skole-/ } \\
\text { hjemsamtale } \\
\text { Handlings- } \\
\text { planer (dokument) }\end{array}$ & 54 min. \\
Caseskole B & $\begin{array}{l}\text { Læsevejleder 3 } \\
\text { (LV3) } \\
52 \text { min. }\end{array}$ & $\begin{array}{l}\text { Læsevejleder 3 } \\
\text { (LV3) } \\
750 \text { min. }\end{array}$ & $\begin{array}{l}\text { Analyse } \\
\text { Læsekonferencer }\end{array}$ & 52 min. \\
\hline Caseskole C & $\begin{array}{l}\text { Læsevejleder 4 } \\
\text { (LV4) } \\
62 \text { min }\end{array}$ & $\begin{array}{l}\text { Læsevejleder 4 } \\
\text { (LV4) } \\
300 \text { min. }\end{array}$ & $\begin{array}{l}\text { Analyse } \\
\text { PLF-møde på } \\
\text { skolen }\end{array}$ & 60 min. \\
& & &
\end{tabular}

Adgangen til praksis forhandles løbende med læsevejlederne, som også giver adgang til deltagelse i vejledning med lærerne. Adgangen til feltet betinges også af institutionelle rammer og beslutning om, hvornår "jeg må være med", ligesom den må genforhandles over tid. I de semi-strukturerede interviews (Kvale \& Brinkmann, 2015) spurgte jeg til informanternes uddannelse, erfaring, tidligere og nuværende arbejdsopgaver, funktioner og $\emptyset$ nsker i forhold til deres arbejdsopgaver. Jeg spurgte også til, hvilke datatyper de primært arbejder med, samt hvordan læsevejledning er organiseret i kommunen eller på skolen, men også hvilken rolle de som læsevejledere spiller, når det kommer til kollegaer og samarbejdet med ledelsen på skolen. De samme områder blev lederen spurgt ind til, blot set ud fra deres perspektiv. Interviews, feltnoter og lydoptagelser fra observationer indgår i undersøgelsen. Interviews er transskriberede, og alle data er kodet med udgangspunkt i den kulturhistoriske virksomhedsteori, som jeg nu vil udfolde.

\section{Kulturhistorisk virksomhedsteori}

Den kulturhistoriske virksomhedsteori er tidligere blevet brugt til at undersøge arbejdspladser med grupper af ansatte, der har en fælles historie, og som arbejder mod et fælles mål. Derfor er teorien også særlig interessant, når det handler om skole 
(Engeström, 2014; Hasse, 2015, s. 34). Den finske professor Yrjö Engeström har udviklet en teori om virksomhedssystemer. Det har han gjort på baggrund af bl.a. Vygotskys teorier, der anser menneskelig handling og tænkning som forbundne til kultur og historie. Engeström repræsenterer den tredje generation af den kulturhistoriske virksomhedsteori, hvor virksomhedssystemer er helt centrale (Engeström, 2016). Et virksomhedssystem kan fx være et hospital eller en skole. Til hvert af disse virksomhedssystemer knytter sig både bevidste handlinger og ubevidste, rutiniserede operationer. Der er nogen, der gør noget for at opnå et bestemt mål eller resultat. Individer og grupper handler mod et fælles mål, og derfor udgøres virksomheden af et fællesskab, det kollektive. Leontjev (2009) sondrer mellem begreberne virksomhed, handling og operation. Virksomhed udføres af et kollektivt fællesskab, handlingen udføres af individer og er rettet mod et mål, og operation kan forstås som automatiserede operationer, som individet gør brug af i forskellige processer. Alle elementer må derfor ses i denne sammenhæng, det illustreres i Figur 1, som viser to virksomhedssystemer. Det første kalder jeg for virksomhedssystem I, som primært handler om læsevejlederens vejledning af læreren med test. Virksomhedssystem II fokuserer på lærerens arbejde med testen via læremidler med eleven. Objektet kan forstås, som det virksomheden er rettet mod. I virksomhedssystem I handler det om læreren, hvor det i virksomhedssystem II handler om eleven (Knutagård, 2013, s. 147). Artefakter er i denne sammenhæng testdata i virksomhedssystem I og læremidler i virksomhedssystem II. De to virksomhedssystemer har et delt formål, nemlig elevens faglige udvikling. 


\section{Virksomhedssystem I}

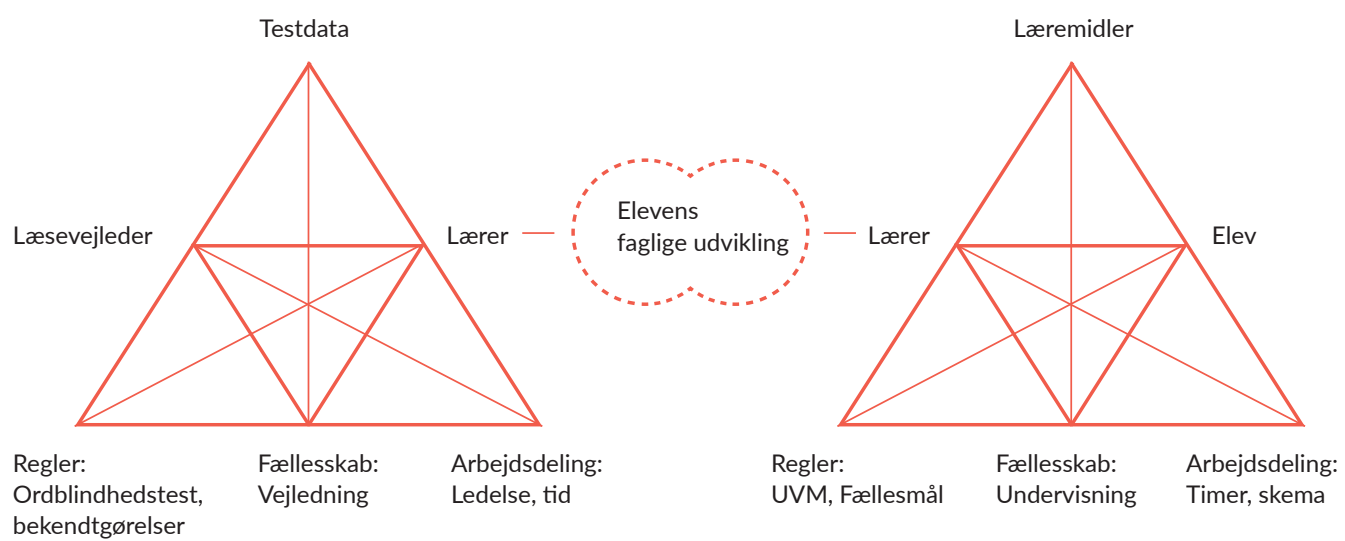

Virksomhedsteoriens begreber og modeller tilbyder både et fokuseret, men samtidig nuanceret indblik i forhold til spændinger $i$ og mellem forskellige virksomhedssystemer. I denne artikel er det spændinger, som læsevejlederne oplever, når de skal vejlede lærere i relation til testdata. Alle elementer i virksomhedssystemet, regler, arbejdsdeling, foellesskab og artefakter, subjekter og objekter, ses dialektisk forbundne med hinanden, og det giver mulighed for få øje på sammenhængsforståelser i de spændinger, som læsevejlederen oplever. Spændinger er historiske, og de kan ifølge Engeström beskrives inden for fire niveauer af modsætninger. Primore indre modscetninger ses i alle bestanddele i virksomhedssystemet, fx når læsevejlederen ønsker at vejlede mere ude i klasserne, hvor arbejdsdelingen gør dette vanskeligt. Sekundcere modscetninger ses, når et nyt element som fx nye test kommer ind i skolen. En terticer modscetning opstår, når objektet, altså retningen, for den fremherskende form for virksomhed gøres mere avanceret. Her findes modsætningen i et mere overordnet virksomhedssystem, og det er, fx når man ønsker en skole, der i større udstrækning er baseret på data. Det kan betragtes som en mere avanceret form for skole end den traditionelle. Den kvartcere modscetning ses mellem den centrale virksomhed, her det system, hvor læsevejlederen arbejder med test sammen med læreren, og det virksomhedssystem, som læreren virker i, her læreres arbejde med læremidler sammen med eleven. Det omfatter også virksomhedssystemer, der producerer redskaber til den 
centrale virksomhed, fx producenter af test og læremidler. Det er også andre virksomheder, der påvirker, fx uddannelsessektoren. Til sidst er der også virksomhedssystemer, der vedhører lovgivning, regler og administration, fx den kommunale forvaltning, Undervisningsministeriet (UVM) m.fl. (Knutagård, 2013; Engeström, 2001; Engeström, 2014; Daniels, 2008).

Spændinger opstår, fordi virksomheden er en del af samfundets samlede produktion på den ene side og menneskets eget eller uafhængige virksomhed på den anden side (Knutagård, 2013, s. 149). Kuutti (1996) forklarer, at "[a]ctivity theory uses the term contradiction to indicate a misfit within elements [i et virksomhedssystem], between them, between different activities, or between different developmental phases of a single activity" (Kuuti, 1996, s. 34). Spændinger lader sig ikke så let observere, de må udledes gennem historiske og empiriske analyser ${ }^{3}$, hvor der kigges på, hvordan tingene har været praktiseret i virksomhedssystemet og mellem virksomhedssystemer tidligere sammenlignet med nu. Handlinger mellem subjekt, objekt, medieret af et artefakt i virksomhedssystemet, kan iagttages udefra, fx gennem skygning. Her kan jeg iagttage, hvad læsevejlederen gør med testdata og læremidler, og lytte til hvilket fagdidaktisk sprog, der bruges. Derimod kan det være vanskeligere at iagttage regler, arbejdsdeling og fællesskaber gennem skygning, men i interviews kan jeg få øje på sammenhænge og spændinger mellem regler, arbejdsdeling, fællesskaber, subjekter, objekter og artefakter i virksomhedssystemet (Engeström, 2019, s. 44). I det følgende afsnit vil jeg uddybe modellen ved at sige noget om artefakter, regler, fællesskaber og arbejdsdeling.

\section{Artefakter}

Artefaktbebegrebet var Vygotsky især optaget af, da det medierer handlingen mellem subjektet og objektet (Vygotsky, 1978). Og netop udviklingen af kulturelle artefakter er også central i Engeströms teori. Ikke mindst derfor er teorien både aktuel og interessant, når det kommer til brugen af testdata, som er et kulturelt artefakt. I indeværende artikel drejer det sig om artefakterne test og læremidler, som har til formål at lede til forandring. Artefakter er både fysiske og symbolske, og de er med til at forme 
den menneskelige virkelighed gennem kulturelle repræsentationer. Artefaktets funktion er:

99

to serve as the conductor of human influence on the object of activity; it is externally oriented; it must lead to changes in objects. It is a means by which a human external activity is aimed at mastering, and triumphing over, nature.

(Vygotsky, 1978, s. 55)

Et artefakt kan have flere forskellige betydninger afhængig af kontekst (Engeström, 2014). Intentionen med artefakter er, at det leder til forandringer i virksomhedssystemet i forhold til målet. Både testdata og læremidler skal bidrage til et delt fælles mål: Elevens faglige udvikling (se Figur 1). Testdata har også den funktion at bidrage til indsigt $i$ og vurdering af elevens faglige udvikling i forhold til specifikke faglige områder. Artefakterne kan betragtes som redskaber, man kan tænke med (Hasse, 2015, s. 83). Ikke kun fysiske artefakter, men også sproget er til stede i virksomhedssystemerne. Sproget betragtes som et symbolsk artefakt, og Vygotsky tillægger da også sproget en særlig betydning (Hasse, 2015, s. 77). Inden for databrugsforskningen er der også en særlig måde at tale om data og test på, kaldet data literacy (Mandinach \& Gummer, 2013). Det kan også være, at der er et særligt fagsprog i virksomhedssystemet hos fx læsevejlederen (Knutagård, 2013, s. 67). Det er væsentligt at bemærke, at man ikke kan sikre brugen af artefakter, selvom de er til stede. Regler spiller også en rolle i virksomhedssystem I og II.

\section{Regler}

Regler har som formål at styre virksomhedssystemets aktiviteter i forhold til målet. De kan være eksplicitte og implicitte bestemmelser, normer og konventioner, som har til hensigt at styre handlinger og interaktioner inden for virksomhedssystemet (Sannino \& Engeström, 2018, s. 45). Regler er med til at karakterisere, hvad der skal ske, hvornår, med hvem, hvordan osv. Reglerne kan man se gennem beslutninger i forhold til arbejdsdeling, og de besluttes af UVM eller forvaltningen gennem love og bekendtgørelser. Regler har også indflydelse på fællesskaber. 


\section{Fællesskaber}

Fællesskaber består af flere personer, der deler ønsket om at nå et fælles mål (Knutagård, 2013, s. 148). Fællesskaber kan forstås som måder at være sammen om undervisning på. Fællesskaber er defineret af regler, og de kan opstå som følge af behov og påvirkning fra både subjekter og objekter i virksomhedssystemerne. Fællesskabet i system II handler om det, som lærerne gør i undervisningen med eleverne, og det ønsker virksomhedssystem I at påvirke gennem vejledning. I empirien kan jeg kun iagttage virksomhedssystem II gennem læsevejlederens forslag af læremidler. Det betyder, at jeg ikke observerer, hvad og hvordan læreren gør. Vejledning kan være alt lige fra læsekonferencer, uformel snak hen over kaffen i pausen, mails eller beskeder på AULA, vejledning mellem læsevejleder og lærer, modellering eller observation i klasserummet m.fl. Vejledningsformen afhænger af både arbejdsdeling, dvs. tid og mulighed for at mødes, men også af, i dette tilfælde, lærerens behov og ønsker i forhold til vejledning.

Fællesskabet handler i virksomhedsssystem II om undervisning, og en del af undervisningen handler om mål for eleven, differentiering, organisering af undervisningen som fx gruppearbejde eller klasseundervisning. Om virksomhedssystemet skriver Engeström da også, at målet altid er under konstruktion, det er fortolket og formet af de aktører, der er involveret i virksomheden (Engeström, 2019, s. 44).

\section{Arbejdsdeling}

"Division of labor refers to horizontal division of tasks and vertical division of power and status" (Sannino \& Engeström, 2018, s. 45). Arbejdsdeling handler om, hvem der skal gøre hvad set i relation til målet. Derfor vil de forskellige personer i virksomhedssystemet udføre forskellige handlinger med forskellige artefakter. Spørgsmålet om, hvad en lærer, en læsevejleder og en leder skal foretage sig i virksomhedssystemerne, vil være forskelligt. De virker under forskellige love, bekendtgørelser og regler. Arbejdsdelingen foregår altså mellem virksomhedens mellemmer, og de forskellige positioner spiller også ind på arbejdsdeling, det kan være magt og status (Knutagård, 2013, s. 148). Derfor vil arbejdsdelingen og dens magtstrukturer også være påvirket af det omkringliggende samfunds magtstrukturer. Rollerne bliver forskellige, og det kan også afhænge af den ekspertise, man har eller tildeles i virksomheden. 


\section{Analyse}

Ovenfor har jeg præsenteret centrale begreber i Engeströms virksomhedsteori, og med udgangspunkt i disse begreber foretager jeg nu en analyse af det empiriske materiale. Jeg analyserer interviews, feltnoter samt dokumenter gennem et kulturhistorisk virksomhedsteoretisk perspektiv for at undersøge spændinger, der opstår i og mellem virksomhedssystemer. Først analyserer jeg regler, så arbejdsdeling og sidst artefakter og fællesskab med udgangspunkt i Figur 1.

\section{Regler}

Virksomhedssystemerne er påvirket af regler vedtaget af UVM. I forhold til læsevejledere er det bekendtgørelsen for læsevejledning i skolen, som bekendtgør, hvad en læsevejleder skal arbejde med. I Folkeskoleloven står der, at elevers udbytte løbende skal evalueres, det gøres på alle case-skoler ved hjælp af test. Det er også vedtaget lovmæssigt, at undervisningen skal planlægges ud fra Fælles Mål for folkeskolens fag. Fra ministeriel side er der truffet beslutning om, hvornår nogle test kan gennemføres. Den digitale og obligatoriske ordblindetest er fx åben fra 1. marts og frem til sommerferien (UVM, 2020b) og er således bestemmende for, hvornår elever testes for dysleksi på case-skolerne. Det påvirker rutinerne i skolen og skaber nogle spændinger. Læsevejlederen får en ny opgave, fordi en ny regel, som denne, bliver vedtaget. Den nationale ordblindetest kan kun gennemføres fra 1. marts og frem til sommerferien, og den tages af elever fra 3. klasse og opefter, som allerede har vist tegn på vanskeligheder. Ordblindetesten bruges af fagpersoner med viden om læsning og læsevanskeligheder (UVM, 202ob), og det er skolens ledelse, der beslutter hvilke elever, der skal testes med ordblindetesten (UVM, 202Ob).

Når testen alene må tages i et begrænset tidsrum, ser jeg, at læsevejlederne tester med andre test i mellemtiden, fx Elbros ordlister, IL-ungdom ${ }^{4}$ m.fl. Regler får altså betydning for, hvilket artefakt læsevejlederen anvender i sin afdækning af eleven, fordi hun ikke kan vente på, at den nationale ordblindetest må gennemføres. Der må handles hurtigt, hvis en lærer eller en forælder udtrykker bekymring om elevens faglige udvikling. Der

4. Diagnostisk prøve til beskrivelse og vurdering af større børn og unges læsefærdighed, læsestrategianvendelse, læsevaner og læserselvvurdering samt fortolkningsevne. 
er tale om en bekymring, der er baseret på lærerens iagttagelser og tidligere gennemførte stave- eller læsetest, hvor eleven viser tegn på faglige vanskeligheder. Hvis elever i fx 7. klasse viser vanskeligheder i september eller oktober, er det lang tid at vente til marts ${ }^{5}$, hvor den nationale ordblindetest må tages. Det betyder, at læsevejlederen finder andre test at afdække elevens vanskeligheder med. Det er nemlig hendes opgave sammen med læreren at sikre elevens faglige udvikling og iværksætte tiltag, som hjælper eleven.

På case-skole A har den ene læsevejleder udarbejdet en handlingsplan, hvori der beskrives nogle af de tiltag, som læsevejlederen på baggrund af nuværende testdata vurderer hensigtsmæssige i forhold til en elev. Der er tale om både test, som er taget $\mathrm{i}$ indeværende skoleår, IL-ungdom (fordi de venter på den nationale ordblindetest) og ST-prøver tilbage fra 3. klasse, som viser elevens udvikling. Dertil kommer lærerens iagttagelser fra undervisning. Der foreslås bl.a., at eleven begynder at bruge LST, som fx IntoWords og lignende, der kan hjælpe med ordoplæsning eller ordforslag, men det foreslås også, at læreren tænker i en dysleksivenlig undervisning, også selvom eleven ikke er testet med den nationale ordblindetest. Forslagene målrettes, så de ikke kun imødeser en mulig problemstilling vedrørende dysleksi, men også har en mere overordnet karakter i forhold til danskundervisningen. Der foreslås bl.a. at arbejde med læsestrategier, gentaget læsning, lærermodellering af tekster, og der foreslås konkrete læremidler som Mivo, Margit Gades skriveskabeloner, notatteknikker fra www.undervis.dk m.fl. i en elevs handleplan. Opsummerende kan jeg sige, at det for case-skole A gør sig gældende, at der er en spænding internt i virksomhedssystem I mellem de regler, der er for ordblindetestning og arbejdsdelingen, som handler om læsevejlederens vejledning af læreren med artefakterne; testdata og læremidler. Det, der foregår i virksomhedssystem I, får dermed betydning for det, læreren kan gøre med eleven i virksomhedssystem II. Læsevejlederens forslag til undervisningsmetoder og læremidler bliver af mere generel karakter, fordi den rigtige ordblindetest ikke kan foretages. 


\section{Arbejdsdeling}

Arbejdsdeling er en fordeling af ansvar og opgaver, som læsevejlederen skal varetage, og det aftales årligt i en funktionsbeskrivelse med skolens ledelse på alle case-skoler. Læsevejlederen skal både arbejde sammen med lærerne, men også med skolens ledelse. Kompetencemålene fra læsevejlederuddannelsen (Studieordning, 2017) udpeger rammer for læsevejlederens virke. Ifølge disse kompetencemål handler læsevejlederens opgave om at identificere, afdække og vejlede elever med skriftsprogsvanskeligheder. De skal også forestå den løbende udvikling af handleplaner og didaktiske tiltag for skriftsprogsundervisningen i dansk og andre fag i skolen. Læsevejlederen skal være i stand til at kunne vejlede lærere i forhold til indhold, metoder og materialevalg (fx læremidler) inden for læsning og skrivning, desuden skal de fortolke og formidle testresultater til forskellige aktører som skoleledelse, lærere/kollegaer og forældre. De skal "kunne vejlede i formativ anvendelse af test og evalueringsresultater" (Studieordning, 2017, s. 36). I målene understreges det, at en læsevejleder skal kunne vejlede kollegaerne, så de kan tilrettelægge og gennemføre en differentieret og inkluderende skriftsprogsundervisning, som tilgodeser alle elever i den almindelige undervisning. Imidlertid opstår en spænding i forhold til det, som læsevejlederne skal, og det behov, som lærerne har. Når jeg spørger læsevejlederne, så svarer de, at lærerne ønsker, at de giver dem råd, og noget der hurtigt kan omsættes i deres undervisning, og det er læremidler et eksempel på:

I: " Hvilken rolle spiller loeremidler i sådan en rådgivningssituation?"

LV 3: "Jamen, det spiller jo også en rolle. Det har jeg her på det seneste ikke haft tid til at kigge på. Men jeg har førhen, når jeg har haft loesekonference eller snakket med folk, så har jeg altid haft et eller andet, hvor jeg har toenkt, jamen, det her finder jeg lige frem, for det kan voere godt lige at gi. De kan godt lide at få noget med $i$ hånden. Og det er jeg gået lidt voek fra, for jeg har jo heller ikke tid. Jeg er skåret på tiden.”

I det øjeblik, at der ikke længere er tid til dette, opstår en spænding i det fællesskab, som handler om vejledning. Der er altså forskellige forventninger til vejledning, alt efter om man er læse- 
vejleder eller lærer. Læsevejlederen oplever en spænding, når det kommer til egne ambitioner og andres forventninger. En læsevejleder vil gerne vejlede på andre måder end alene via læremidler, som dette citat viser:

I: "Hvad ville de [loererne] have for 10 år siden, og hvad vil de have i dag?"

LV 3: "Det er det samme; helt konkrete råd, ikke sådan en helt masse .... Jo, altsåjeg har da holdt nogle oploeg, som vi snakkede om før om faglig loesning osv. osv. Og nogen ved, jeg også har vœeret ud at prøve det af, men der er jo også nogen der sådan ... Ja. Nu har vi hørt det og såja. Og der giver det så meget mere, hvis man er ude $i$ klasserne og vore der og måske siger: "Skaljeg prøve lige at starte den her time op? Skal jeg prøve at vise, hvordan jeg kunne gribe det her an med at loese den her fagtekst?" Så kan loereren stå og observere, hvordan gør du egentlig?"

I: "Den oplevelse du har der, når du fremhoever den som scerlig god, er det så, fordi du har fået en respons på den fra den pågceldende loerer? Hvilken feedback får du på det?"

LV 3: "Jamen, så har jeg egentlig hørt, at de ligesom siger, jamen, det har jeg slet ikke toenkt på at gøre det på den måde. Og det er jo sådan set lige proecis det, som jeg gerne vil. For det er klart, hvis man er en rigtig dygtig faglcerer $i$ biologi og historie, og hvad det kan voere, så går man måske ikke så meget ind i det loesetekniske og ser, hvad kan voere svoert ved den her tekst, og hvilken loeseretning kan man have, og hvor skal vi starte? Der er det måske svcerere at scette sig ind i det som fagloerer."

Læsevejlederne ønsker at gå med ud i klasserne, hvor de kan observere og modellere, fordi de kan se, at lærere får øjnene op for noget, de ellers ikke ville have fået. Men dette er ikke altid muligt, fordi andre opgaver presser sig på. Den lokale arbejdsdeling er påvirket af regler, og det ses eksempelvis, når UVM træffer beslutning om at indføre en national ordblindetest. Så øver det indflydelse på læsevejlederens arbejdsopgaver, og det betyder, at tiden må prioriteres anderledes, fx i samarbejde med ledelsen. Det betyder også, at tiden til at sætte sig ind i nye læremidler, som de tidligere har brugt tid på, ikke længere prioriteres i 
arbejdsdelingen. Læsevejlederen kommer ikke ud i klasserne og ser, hvordan lærerne arbejder med faglig læsning, i forhold til fx læremidlerne og undervisningen i naturfagene, eller deltager på teammøder eller som hun selv udtrykker det "sætte nogle ting i søen" (LV3, interview case-skole B). Noget udvikling må nedprioriteres og vente, når nye regler indføres. På case-skole B har fokusset på ordblindeindsatsen betydet, at andre indsatser i læsevejledningen må nedprioriteres, det er ledelsen bevidst om. Læsevejleder på case-skole B beskriver det sådan her: "Lige så snart man er testet ordblind, så træder en hel masse i kraft. Og hvem skal tage sig af det? Jamen, det skal læsevejlederen, som det er lige nu". Når en kommune har en særlig indsats omkring dysleksi, kan det betyde, at tiden fra fx det at holde sig orienteret i læremidler får et andet fokus end tidligere. Det betyder ikke, at læsevejlederen ikke har en opmærksomhed på læremidlerne, men fokus ændrer karakter og orienterer sig mod dyslektiske elever. Læsevejlederen på case-skole B siger: "Altså lige nu arbejder vi jo rigtig meget på at blive en dysleksivenlig skole. Så vi prøver at slå et slag for, at de læremidler, man vælger, at den litteratur, man vælger, kan findes elektronisk". Så fokus på læremidlerne har ændret karakter, når man spørger læsevejlederne. Det handler bl.a. om en øget digitalisering af læremidlerne, således at de elever, der har behov for det, kan anvende LST sammen med læremidlerne. Det ses især, når læsevejlederen vejleder lærere, at LST bliver foreslået. Selvom ordblindetesten endnu ikke er taget, og eleven ikke er konstateret ordblind, ses der eksempler på i observationer og handleplaner, at LST foreslås på lige fod med andre læremidler eller undervisningsstrategier (observation, case-skole A).

Læsevejlederen må også bruge tid på at holde kurser for eleverne i LST eller i nogle tilfælde gå med ud i klasserne og støtte de elever, der har brug for hjælp til LST i den daglige undervisning, men også i testsituationer (LV 3, interview, case-skole B). Arbejdsdelingen skifter karakter over tid, og det afhænger af nationale, kommunale og lokale indsatser. Det opleves som en spænding hos læsevejlederen, fordi der så ikke længere er tid til det, som hun har oplevet som meningsfuldt.

\section{Artefakter og fællesskaber - vejledning og undervisning}

Jeg analyserer nu forholdet mellem artefakter og fællesskaber (vejledning og undervisning) i ét afsnit, fordi der ofte indgår artefakter i de vejledningsrutiner, jeg har observeret. Fællesskabet 
i virksomhedssystem I handler om lærere og læsevejlederes måder at samarbejde på. Der kan fx være tale om vejledning, som både kan være formel, dvs. aftalt eller en rutine som $\mathrm{fx}$ læsekonferencer, eller uformel snak hen over kaffen i pausen. Men hvordan gribes forholdet mellem testdata og undervisning an i vejledningssituationer? Observationerne viser, at der optræder flere artefakter i forholdet mellem læsevejlederen og læreren. Først og fremmest er det testen, hvorigennem elevens vanskeligheder og potentialer afdækkes. Andre artefakter, som er til stede, bl.a.: skærme, papirer, hæfter, testresultatoversigter, datavisualiseringer og elevprodukter. Der er tale om fysiske og visuelle artefakter. Nogle medbringes af læsevejlederen andre af læreren. Et andet symbolsk artefakt er det fagdidaktiske sprog, som udveksles mellem læsevejleder og lærer. Der kan bl.a. nævnes, at der tales om særlige metoder, læsestrategier, notatteknikker, gentaget læsning, staveudvikling m.fl. Inden vejledning har læsevejlederen analyseret data. Til alle diagnostiske test, som Bogstavprøve, Ordlæseprøve, Sætningslæseprøve og Staveprøve fra Hogrefes analoge test, er der en tilhørende vejledning med afsnit, der forklarer, hvordan man kan gå fra test til undervisning. Der er i alle vejledningerne et afsnit omhandlende "Fra prøveresultat til undervisning" (Juul, 2012; Juul \& Møller, 2009), desuden er der en litteraturliste, som både består af det, man kan kategorisere som pædagogisk litteratur til læreren, men også semantiske læremidler (Hansen, 2010). Empirien viser, at læsevejlederen gerne bruger vejledningsbogen og henter inspiration fra den, når hun skal bygge bro fra test til undervisning (LV 1, observation). De foreslåede læremidler og undervisningsmetoder i testvejledningerne bliver kun opdateret, når der kommer en ny testvejledning. Det, der kendetegner disse vejledninger, er, at de mere generelt formulerer forslag eller idéer til forskellige undervisningsmetoder og strategier, og det omtales sådan: Herudover får du tips og gode råd til, hvordan du bruger prøveresultatet fremadrettet i din undervisning (Juul, 2012; Juul \& Møller, 2009). Læremidlerne udgør en central del af lærerens undervisning, så forholdet mellem test og læremidler står tilbage som en opgave, læsevejlederen kan hjælpe til med at løse. Forholdet mellem test og læremidler udgør en spænding, fordi testen i sig selv ikke foreskriver et bestemt valg eller en bestemt brug af læremidler. I forhold til måder at stille forslag om at bruge læremidler i forhold til testdata, så ser jeg fem overordnede mønstre og spændinger: 
Forslag om

1. brug af læremidler og en bestemt organisering,

2. brug af læremidler inden for et bestemt fagligt område som læsning, stavning og grammatik,

3. fravalg af læremidler og undervisningsmåder,

4. brug af $L S T$,

5. brug af andre undervisningsmetoder eller tilgange.

Mønstrene og de spændinger, som opstår, udfolder jeg i det følgende. Det er kun intentionen, jeg har mulighed for at analysere. Der kan være en divergens imellem det, der foreslås og er læsevejlederens intention og det, der rent faktisk praktiseres i undervisningen. Læsevejlederen har ofte ikke mulighed for at gå med ud i undervisningen, som de også selv beretter om i interviews. Derfor er det usikkert, hvilken betydning didaktiske forslag på baggrund af testdata og forslag om brug af læremidler eller metoder får for elevens faglige udvikling.

\section{Brug af loeremidler og en bestemt organisering}

I empirien ser jeg eksempler på, at læremidlet VAKS medfører en særlig organisering. Det kan dreje sig om undervisning mellem en læsevejleder og elever eller mellem en lærer og elever. Det omtales som et særligt kursus på klassen eller mindre hold med læremidlet VAKS. Der er tale om et læremiddel, der arbejder med en faglig problemstilling eller strategier inden for læsning, og det foreslås til elever, der viser tegn på læsevanskeligheder. Det drejer sig fx om elever, der lander i kategorien Co- C2 i stavetesten, eller elever, der klarer sig dårligt i DVO-screeningen. Elever, der viser tegn på disse vanskeligheder, samles på hold og tilbydes et kursus med VAKS (Funktionsbeskrivelse case-skole A, Interview LV 1 case-skole A, Observation case-skole A og B). Det er ifølge den ene læsevejleder ( $L V$ 3) væsentligt at arbejde med VAKS forud for at kunne bruge LST "hun [eleven] er i nogle situationer for svag til at bruge stavehjælpen i CD-ord... [... Det er ikke nok at kunne CD-ord” (observation, case-skole B). En spænding opstår, hvis læsevejlederen eller en anden kvalificeret ikke får tid til at varetage dette VAKS-kursus ${ }^{6}$.

På case-skole A er der en måde at organisere staveundervis-

6 Læsekurset som undervisningsmetode er uddybet af Hagtvet, Frost \& Refsahl (2016) i kapitel 4. Og for en yderligere diskussion af VAKS, se også Petersen (2012). 
ning på kaldet lodret stavning. Her tilrettelægges undervisningen på tværs af årgange på mellemtrinnet i nogle af timerne, og modsat første eksempel med VAKS, organiseres undervisningen altså ikke ud fra et læremiddel. Eleverne inddeles efter det staveudviklingstrin, som de vurderes til at være på. Denne vurdering foretages bl.a. ud fra ST-test. Undervisningen tilrettelægges ud fra staveudviklingstrinnet, så der foregår en yderligere forfinelse af testresultatet ved at systematisere undervisningen ud fra teorien om staveudvikling (Gjelstrup, 2014). Alle elever fordeles på forskellige hold afhængigt af staveudviklingstrin. Denne måde at organisere undervisning forudsætter tid til at teste og analysere for derefter at placere eleverne ind på hold, og det er læsevejlederen, der står for det (observation case-skole A). Indplaceringerne af elever kræver løbende revidering på baggrund af andre data end test, fx elevprodukter der viser, hvordan elevens staveudvikling er. Denne udvikling fører læsevejlederen i et skema, hun er tovholder på. Denne måde at samarbejde på, stiller krav om kommunikation og koordinering mellem alle lærere på de respektive klassetrin. Imidlertid oplever læsevejlederne, at der blandt nogle lærere er modstand mod denne undervisningsform, og læsevejlederne er ikke sikre på, at undervisningen foregår, som teorien foreskriver det. Der er en spænding i det at arbejde med fx lodret stavning, som er baseret på en særlig teori, og det nogle af lærerne ønsker og faktisk udøver i praksis (Observation, case-skole A).

\section{Forslag om loeremidler inden for et bestemt fagligt område som loesning, stavning og grammatik}

Hvis testdata viser, at en elev har mangelfuld læseforståelse og en lav læsehastighed, foreslås det eksempelvis at bruge BookBites. BookBites er et digitalt læremiddel, der arbejder med elevers læselyst, læseforståelse og læsehastighed. Her er tale om et læremiddel, som kommunen har investeret i, og som stilles til rådighed på skolerne. Læremidlet giver mulighed for at logge data, dvs. både hvordan lærere bruger det og om de bruger det, men det giver også mulighed for at monitorere elevens læseudvikling. Læsevejlederen fortæller i en vejledningssituation om læremidlets muligheder, bl.a. at læremidlet giver mulighed for, at eleven kan markere et ord og få det slået op som et billede på google. Eleven kan "læse med ørene", altså bruge LST. Desuden er der mange nye bøger at vælge imellem på forskellige niveauer, ligesom det også kan måle, hvor hurtigt en elev læser. Læsevejlederen har her en dyb indsigt i læremidlets funktionali- 
teter. En spænding i forhold til forslaget om brugen af BookBites er, hvis der ikke er nok iPads eller andre teknologier, hvor det digitale læremiddel kan afvikles på, i skolen eller i hjemmet (observation case-skole B).

Grammatip er et digitalt læremiddel, hvor elever bl.a. har mulighed for at arbejde med grammatiske områder og særlige fejltyper inden for stavning. Det er et læremiddel, som de fleste lærere i forvejen bruger i deres undervisning og derfor kender godt, ifølge læsevejlederne. Udfordringen er, ifølge den ene læsevejleder, at lærerne ikke altid ved, at de ikke kan nøjes med at træne den fejltype, som eleven viste sig at have vanskeligheder ved, jf. ST-testen. Det handler om elevens staveudvikling: "Jeg ved, at man førhen har givet dem nogle ekstra opgaver i den fejltype, men man har ikke kigget efter stavetrinnene, så den fejltype kunne godt ligge i trin 4, hvor man egentlig kun var på stavetrin 2." (LV 1, interview, case-skole A).

Læsevejlederen peger her på en spænding i forholdet mellem testresultatet og brugen af læremidlet Grammatip, da træningen i sig selv ikke sikrer elevens faglige udvikling inden for fx stavning. Læsevejlederens fagdidaktiske viden om staveudvikling bliver afgørende, når det handler om hensigtsmæssig brug af eksempelvis staveresultater i forhold til læremidlet Grammatip. Selvom læremidler kan hjælpe på nogle områder, er det afgørende, at der er mulighed for, at læsevejlederen kan vejlede i brugen af testdata, set i forhold til læremidler, og bringe sin fagdidaktiske viden og ekspertise i spil, men det er ikke altid at arbejdsdelingen muliggør det. Læsevejlederen oplever, at lærere henvender sig i forhold til testresultater, som de ikke forstår:

LV 1: " Jeg tcenker bare om sådan noget, som jeg bliver spurgt om. [En loerer spørger:] "Jeg kan ikke forstå...nu har han arbejdet med -ene og -ende i så lang tid, og han forstår det stadigvoek ikke. Hvorfor gør han ikke det?” Så kan jeg sige, jamen, det er, fordi han har sprunget alle de andre stavetrin over. Og så nytter det ikke noget. Så kan man troene det her lige så loenge man vil, hvis han [eleven] ikke er nået til det punkt til at nå til det der."

Læsevejlederen har en viden om staveudvikling, og denne viden er væsentlig i forhold til testresultater, fordi man ifølge læsevejlederen ikke kan drage den slutning, at har eleven vanskeligheder med -ene/-ende, så skal eleven træne dette specifikt. Det frem- 
træder tydeligt i citatet ovenfor her, hvor læsevejlederen netop ved, at elevens udfordring med -ene/-ende forveksling ikke kan løses ved at træne denne form for fejl. Eleven må til et andet staveudviklingstrin først for at kunne nå til -ene/-ende.

\section{Forslag om fravalg af loeremidler og undervisningsmåder}

I empirien ses også eksempler på læsevejlederens ønske om fravalg af nogle læremidler. Det er indirekte relateret til testdata og handler om målet om elevens faglige udvikling. Læsevejlederen forsøger at bringe sin faglige viden i spil ved at argumentere mod læremidlet "Skriftlig for", et læremiddel som vanligt købes ind, eller hun argumenterer mod undervisning i diktater, fordi læsevejlederen gennem sin uddannelse og på kurser og videreuddannelse har lært, at det ikke er den bedste måde at arbejde med elevers staveudvikling på. Det viser sig dog at være yderst vanskeligt:

I: "Kan du ikke fortcelle lidt om, hvad du har gjort? Hvordan har du forsøgt som loesevejleder at få det ud, det her loeremiddel?"

LV 1: "Jeg har prøvet at give alle de argumenter, som jeg har loest mig til, dengang, jeg kan ikke huske alle argumenter. Men alt hvad jeg har loest mig til, alt hvad der er blevet sagt, når jeg har voeret på kursus omkring de ting. Jeg har så prøvet at gå hjem og formidle til dem [loererne] uden held. Og det samme goelder jo egentlig diktaterne. Altsåjeg har jo sagt til dem i overbygningen, at de ikke skal køre alle de diktater, men de skal gå ind og kigge på det, de [eleverne] skriver. Men det hjoelper heller ikke noget."

Der er nogle måder at vælge læremidler på, hvor læsevejlederens faglige ekspertise ikke bruges. Måske fordi der ikke har været en tradition for at inddrage læsevejlederen i læremiddelvalg, men at det mere har været op til den enkelte lærer eller fagteam. Diktaten i danskundervisningen er vanskelig at udfordre, måske fordi den har været praktiseret i skolen igennem mange år, måske fordi den stadig er tilbagevendende ved folkeskolens prøver i dansk (Kabel, 2017). Der er en spænding, hvis der er ikke et fællesskab, hvor sådanne ting kan drøftes. 


\section{Forslag om brug af LST}

LST bruges sammen med andre læremidler. Hvis en elev viser tegn på dysleksi eller testes rød eller gul i den nationale ordblindetest iværksættes tiltag med LST. Det gøres på to forskellige måder. På case-skole A foreslås træning i brugen af LST med læremidlet Mivo. Mivo træner elever i at bruge skrivestøtten og de strategier, som knytter sig til at bruge LST. Når eleverne skal lære at bruge LST, kan det organiseres på flere måder, enten ved at læsevejlederen holder kurser i brugen for lærere, ved at læsevejlederen underviser små grupper af elever, eller at læsevejlederen går med ind i den normale undervisning og støtter de elever, der har brug for hjælp med LST. På case-skole B foreslår læsevejlederen, at elever først får et VAKS-kursus, inden LST sættes i værk, fordi de ellers ikke kan bruge deres LST. Der er altså tale om en særlig form for progression, og læsevejlederen vurderer, der er noget, de skal lære i og med VAKS, inden de kan arbejdet med LST (Observation, case-skole B). Det er uklart, hvilken testscore eller kategori (rød eller gul), eleven skal have for at have præcis gavn af LST. Alligevel vurderer læsevejlederen, at mange elever, og ikke kun elever, der når den røde kategori, kan have gavn af at bruge LST. En spænding opstår, hvis læreren vælger læremidler, hvor det ikke er muligt at bruge LST og de tillærte strategier sammen med det.

\section{Forslag om brug af andre undervisningsmetoder eller tilgange}

Der ses eksempler på, hvordan læsevejlederen foreslår læremidler, der arbejder med andre tilgange og metoder, end de praktiserede. Der bruges dels testdata, men også mere formative data, her elevprodukter. I analysen forud for læsekonferencerne ser læsevejlederen, at den ene klasse arbejder med skriveundervisning i hæftet med skriveopgaven: "hvad har du lavet i weekenden?", mens parallelklassen arbejder med læremidlet Skriv og Læs. Derudover kigger læsevejlederen på test. Det, som læsevejlederen når frem til i sin analyse, er, at klassen, der arbejder med Skriv og Læs, skriver langt mere og mere varieret end den klasse, der alene skriver i hæftet med en fast tilbagevendende skriveopgave. Til læsekonferencen drøfter de skriveundervisningen i den klasse, der arbejder med hæfter. Læsevejlederen gør noget ud af at fortælle til læsekonferencen, at det ikke er et læremiddel, læreren behøver at bruge, men noget man kan. Læsevejlederen nævner potentialer i sin vurdering af læremidlet, fx at eleverne laver en færdig bog, de kan sætte billeder ind i og 
at det måske kan øge motivationen for at skrive og skrive mere varieret (case-skole B). Brugen af Skriv og Læs er imidlertid betinget af adgang til iPads og Chromebooks, hvilket opleves som en spænding, hvis de ikke er tilgængelige, og kan således resultere i et fravalg set ud fra lærerens perspektiv (Observation, case-skole B). Testdata fra fx ST-prøver eller læseprøver ville ikke have vist, hvordan skriveundervisning praktiseres i de respektive klasser. Elevprodukter og den opgavedidaktik, der ligger bag, vil i nogen udstrækning kunne give et blik ind i undervisningens virksomhedssystem (II). Vejledningssituationen, som beskrevet ovenfor, efterlader læsevejlederen uvidende om, hvorvidt den pågældende lærer følger rådet og implementerer en anden skriveundervisning. Det hænger sammen med arbejdsdeling, og hvordan denne arbejdsdeling betinger muligheder for vejledning, herunder opfølgning.

Et andet eksempel er, hvor læsevejlederen (LV 2) sidder i en vejledningssituation med klassens dansklærer. Baggrunden for vejledningen er, at der er taget IL-Ungdomstest på to elever i klassen, fordi der var en faglig bekymring omkring deres læse-, skrive- og staveudvikling, som også en ST-test havde vist. Der er mistanke om dysleksi. I vejledningssituationen foreslås Margit Gades skriveskabeloner, fordi de kan bruges sammen med LST, og fordi de stilladserer eleverne i deres skriveproces ved hjælp af de udformede skriveformål og skriverammer, som læremidlet er bygget op omkring, ifølge læsevejlederen. I klassen arbejder de allerede med novellen som genre, så det er den skriveskabelon, som læsevejlederen viser på Margit Gades hjemmeside. Læsevejlederen viser, hvordan skabelonerne kan bruges ind i den undervisning om noveller, som læreren og eleverne allerede arbejder med. Forskellige notatteknikker, brug af før, under og efter læsestrategier, samt arbejde med morfologi og ordkendskab til især fremmedord foreslås af læsevejlederen. Efter vejledningen sender læsevejlederen en handleplan. Testdata bruges her som afsæt for at foreslå nye metoder inden for læsning, skrivning og stavning.

\section{Konklusion}

Analysen har vist, at der er en række spændinger i forholdet mellem regler, arbejdsdeling og fcellesskab. Jeg kan konkludere, at regler har en betydning for foellesskaber og arbejdsdeling på skolerne. Relationen mellem virksomhedssystemerne I og II er 
afgørende, fordi artefakterne (både læremidler og fagdidaktisk sprog) kan støtte læreres udvikling af undervisning. Den virksomhedsteoretiske analyse har bidraget med en indsigt i disse spændinger. Spændingerne mellem regler, arbejdsdeling og fællesskaber er på forskellig vis enten med til at fremme eller svække den relation. Det kommer til udtryk på forskellig vis.

Læsevejlederens og lærerens måde at arbejde på er underlagt regler, og disse regler får da også betydning for de foreslåede læremidler, fx når der er indkøbt et digitalt læremiddel kommunalt. Og reglerne påvirker også arbejdsdelingen, som har stor betydning for fcellesskabet, altså at have tid til at mødes om vejledning. Arbejdsdelingen kan også være afgørende for måder at kunne vejlede og blive vejledt på. Lærerne oplever det meningsfuldt at få foreslået læremidler, så artefaktet læremiddel spiller en væsentlig rolle. Det kræver tid til, at læsevejlederen kan sætte sig ind i læremidlerne, dvs. finde, analysere og vurdere læremidlernes egnethed i forhold til testresultaterne, og det er ikke altid, tiden er til det. Det, at få foreslået et læremiddel uden vejledning, fører til en spænding, fordi læsevejlederens fagdidaktiske ekspertise derved ikke bringes i spil. Arbejdsdeling for både læsevejleder og lærer bliver da vigtig, da de skal have tid og mulighed for at mødes. Det er ikke altid, at det bliver sådan, da regler har indflydelse på de prioriteringer, der er af læsevejlederens arbejde. Fællesskabet er determineret af arbejdsdeling, som har betydning for prioritering af tid og brug af data. På den ene side ved vi fra forskning, at det kræver reflekterende samtaler om data for at analysere dem, for at forstå dem og for at kunne bruge dem. På den anden side kan det være, at der ikke er den fornødne tid det dette. Læsevejlederne ønsker da også denne dybe vejledningsform, og desuden har de et ønske om at modellere, vise hvordan og observere sammen med lærerne i klasserne. På den anden side ønsker lærerne ikke nødvendigvis denne form for vejledning. Læremidler fungerer i både den ene og den anden form for vejledning. Det kan være en udfordring at bruge testdata uden vejledning, fordi det ikke alene handler om at kunne tolke en tests resultater, men det handler også om at kunne anvende den nyeste viden om fx staveudvikling eller faglig læsning i bevægelsen fra test til undervisning. Og det kan udgøre en spænding, hvis læsevejlederens fagdidaktiske viden ikke bringes i spil. Der er også en udfordring i, at arbejdsdelingen ikke altid muliggør, at læsevejlederen ser, hvordan læreren bruger disse læremidler i undervisningssituationer med elever, altså følger op. 
Som analysen viser, ændrer testdata og de foreslåede læremidler da heller ikke nødvendigvis ved de læremiddelvalg og den sædvanlige læremiddelbrug, som allerede finder sted i undervisningen. I stedet kan man sige, at der med inspiration fra læremidler foreslås en udvidelse af læremidler, tilgange eller metoder at undervise på, en erstatning af de anvendte metoder eller supplement eller et særskilt kursus. Særligt fem mønstre og spændinger har vist sig, når læremidler foreslås: 1) forslag om en bestemt organisering, 2) forslag af læremidler inden for et bestemt fagligt område som læsning, stavning og grammatik, 3) forslag om fravalg af læremidler og undervisningsmåder, 4) forslag om brug af LST, og 5) forslag om brug af andre undervisningsmetoder eller tilgange.

\section{Referencer}

Albrechtsen, T. R. S. (2016). Ressourcepersoner i professionelle læringsfællesskaber, reflekterende dialoger om elevdata. I: F. B. Andersen, Ledelse Gennem Skolens Ressourcepersoner (s. 73-86). Aarhus: Klim.

Andreasen, K. E. (2019). Nationale test set fra børneperspektiv. Viden Om Literacy, 25, 74-79.

Bekendtgørelsen for Læsevejledning i Grundskolen (BEK. Nr. 473 af 10/5/2007). https://www.retsinformation.dk/Forms/Ro710.aspx?id=25346

Bundsgaard, J. (2018): Pædagogisk brug af test. Sakprosa, 10(2). https://doi. org/10.5617/sakprosa.6007

Bundsgaard, J. \& Puck, M. R. (2016). Nationale test-danske loerere og skolelederes brug, holdninger og viden (rapport). Aarhus: DPU, Aarhus Universitet. 10.7146/aul.145.124

Coburn, C. E. \& Turner, E. O. (2011). Research on Data Use: A Framework and Analysis. Measurement: Interdisciplinary Research and Perspectives, 9(4), 173-206. https://doi.org/10.1080/15366367.2011.626729

Coburn, C. E. \& Woulfin, S. L. (2012). Reading Coaches and the Relationship Between Policy and Practice. Reading Research Quarterly, 47(1), 5-30. doi:10.1002/RRQ.0o8

Czarniawska, B. (2008). Organizing: how to study it and how to write about it. Qualitative Research in Organizations and Management: An International Journal, 3(1), 4-20. https://doi.org/10.1108/17465640810870364.

Daniels, H. (2008). Vygotsky and research. Abingdon Oxon: Routledge.

Datnow, A. \& Hubbard, L. (2015). Teachers' Use of Assessment Data to Inform Instruction: Lessons from the Past and Prospects for the Future. Teachers College Record, 117(4).

Engeström, Y. (2019). Medical work in transition: Towards collaborative and transformative expertise. I: Routledge handbook of the medical humanities (1. udg.), s. 41-54. https://doi.org/10.4324/9781351241779-4

Engeström, Y. (2016). Studies in expansive learning: learning what is not yet there. New York, NY: Cambridge University Press.

Engeström, Y. (2014). Learning by Expanding: An Activity-Theoretical Approach to Developmental Research. Cambridge: Cambridge University Press. 
Engeström, Y. (2012). Ekspansiv læring - på vej mod en nyformulering af den virksomhedsteoretiske tilgang. I: K. Illeris (red.), 49 tekster om loering (s. 443-467). København: Samfundslitteratur.

Engeström, Y. (2001). Expansive learning at work: toward an activity theoretical reconceptualization. Journal of Education and Work, 14(1), 133-156. https://doi.org/10.1080/13639080123238

Engeström, Y. \& Sannino, A. (2011). Discursive manifestations of contradictions in organizational change efforts. Journal of Organizational Change Management, 24(3), 368-387. https://doi. org/10.1108/09534811111132758

EVA. (2017): Skolers erfaringer med at anvende data. Lokaliseret den 1. januar 2020 på: https://www.eva.dk/grundskole/skolers-erfaringer-anvende-data

Feldman, M. S. (200o). Organizational routines as a source of continuous change. Organization Science, 11(6), 611-629. DOI: 10.1287/orsc.11.6.611.12529

Gjelstrup, M., Kjær, K. \& Norrbom, L. (2014). Hvordan loerer mine elever at stave?... og lad det ikke voere hemmeligt for dem! : staveundervisning ud fra staveudviklingstrin. (2. udg.). Karlslunde: Læs.

Hagtvet, B., Frost, J., Refsahl, V. \& Pøhler, L. (2016). Intensiv loeseundervisning på mellemtrinnet: en praksisnoer fortoelling om planloegning, gennemførelse og evaluering af tiltag for elever i loese-og skrivevanskeligheder (1. udg.). København: Dansk Psykologisk Forlag.

Hansen, J. (2010). Loeremiddellandskabet: fra loeremiddel til undervisning (1. udg.). København: Akademisk Forlag.

Hansen, T. I., \& Skovmand, K. (2011). Folles mål og midler: læremidler og læreplaner i teori og praksis (1. udg.). Aarhus: Klim.

Hasse, C. (2015). An Anthropology of Learning On Nested Frictions in Cultural Ecologies. Aarhus: DPU, Aarhus Universitet. https://doi.org/10.1007/978-94017-9606-4

Hubers, M. D., Schildkamp, K., Poortman, C. L. \& Pieters, J. M. (2017). The quest for sustained data use: Developing organizational routines. Teaching and Teacher Education, 67, 509-521. doi: 10.1016/j.tate.2017.07.007

Huguet, A., Marsh, J. A. \& Farrell, C. C. (2014). Building Teachers' Data-Use Capacity: Insights from Strong and Developing Coaches. Education Policy Analysis Archives, 22(52). https://doi.org/10.14507/epaa.v22n52.2014.

Ikemoto, G. S., \& Marsh, J. A. (2007). Cutting through the data-driven mantra: Different conceptions of data-driven decision making. I: P. A. Moss (red.), Evidence and decision making, 105-131. Malden: Wiley-Blackwell.

Johnson, B. (2014). Ethical issues in shadowing research. Qualitative Research in Organizations and Management: An International Journal, 9(1), 21-40. DOI 10.1108/QROM-09-2012-1099

Juul, H. (2012). Vejledning til Staveprøve 1-3. Frederiksberg: Hogrefe Psykologisk Forlag A/A.

Juul, H. \& Møller, L. (2009). Vejledning til Bogstavprøve 2. Frederiksberg: Hogrefe Psykologisk Forlag A/A.

Kabel, K. (2017). Hvad gør hvilken grammatik godt for? I: J. Bremholm, J. Bundsgaard, A. K. Skyggebjerg \& S. S. Fougt (red.), Loeremidlernes danskfag (s. 130-150). Aarhus: Aarhus Universitetsforlag. Didaktiske Studier.

Kiær, K. (2020). Læreres databrug - mellem indsigt og valg. I: En moderne og aktuel didaktik (s. 47-81). Frederikshavn: Dafolo.

Kiær, K. \& Albrechtsen, T.R.S. (2020). Forandringer i organisatoriske rutiner: Læsevejledning og testning i skolen som eksempel. Forskning \& Forandring, $3(1), 28-46$. 
Knutagård, H. (2013). Introduktion til den kulturhistoriske virksomhedsteori (1. udg.). Aarhus: Klim.

Kuutti, K. (1996). Activity theory as a potential framework for humancomputer interaction research. I: B. Nardi (red.). Context and consciousness (17-44). Cambridge, MA: MIT Press.

Kvale, S. \& Brinkmann, S. (2015). Interview: Det kvalitative forskningsinterview som håndvcerk (3. udg.). København: Hans Reitzels Forlag.

Lai, M. K. \& Schildkamp, K. (2013). Data-based decision making: An overview. I: K. Schildkamp, M. K. Lai \& L. Earl (red.), Data-based decision making in education (s. 9-21). Dordrecht: Springer. https://doi.org/10.1007/978-94-0074816-3_2.

Leontjev, A. (2009). Virksomhed, bevidsthed, personlighed (1. udg.). København: Hans Reitzels Forlag.

Mandinach, E. B. \& Gummer, E. S. (2013). A systemic view of implementing data literacy in educator preparation. Educational Researcher, 42(1), 30-37. DOI: 10.3102/0013189X12459803

Marsh, J. A., Bertrand, M. \& Huguet, A. (2015). Using data to alter instructional practice: The mediating role of coaches and professional learning communities. Teachers College Record, 117, 1-40.

Marsh, J. A., Sloan McCombs, J. \& Martorell, F. (2010). How instructional coaches support data-driven decision making: Policy implementation and effects in Florida Middle schools. Educational Policy, 24, 872-907. doi:10.1177/08959048093414,67

Mausethagen, S., Skedsmo, G. \& Prøitz, T. S. (2016): Ansvarliggjøring og nye organisasjonsrutiner i skolen - rom for læring? Nordiske organisasjonsstudier, 18(1), 79-97.

McDonald, S. \& Simpson, B. (2014). Shadowing research in organizations: the methodological debates. Qualitative Research in Organizations and Management An International Journal, 9(1). DOI: 10.1108/QROM-02-20141204

Nordenbo, S. E., Allerup, P., Andersen, H. L., Dolin, J., Korp, H., Larsen, M. S., ... Østergaard, S. (2009). Pcedagogisk brug af test. Et systematisk review. København: Danmarks Pædagogiske Universitetsforlag.

Petersen, G. L. (2012). Skriftsprogstilegnelse hos dyslektiske unge og voksne på et sociokulturelt og kommunikativt grundlag (Doctoral dissertation, Institut for Uddannelse og Pædagogik, Aarhus Universitet).

Quinlan, E. (2008). Conspicuous invisibility: Shadowing as a data collection strategy. Qualitative Inquiry, 14(8), 1480-1499. https://doi. org/10.1177/1077800408318318

Sannino, A \& Engeström, Y. (2018). Cultural-Historical Activity Theory: Founding Insights and New Challenges. Cultural-Historical Psychology,14(3), 43-56. doi: 10.17759/chp.2018140304

Schildkamp, K. \& Poortman, C. (2015). Factors Influencing the Functioning of Data Teams. Teachers College Record, 117(4). https://doi.org/10.1080/o92434 53.2016.1256901

Schildkamp, K., Poortman, C., Luyten, H. \& Ebbeler, J. (2017). Factors Promoting and Hindering Data-Based Decision Making in Schools. School Effectiveness and School Improvement, 28(2), 242-258. https://doi.org/10.108 o/09243453.2016.1256901

Studieordning for de pædagogiske diplomuddannelser. (2017). (7. udg.)

Sun, J., Przybylski, R. \& Johnson, B. J. (2016). A Review of Research on Teachers' Use of Student Data: From the Perspective of School Leadership. Educational Assessment, Evaluation and Accountability, 28(1), 5-33. 
UVM (2020a): Rådgivningsgruppen for evaluering af de nationale test. Anbefalinger, januar 2020. Lokaliseret den 6. februar 2020 på: https:// www.uvm.dk/aktuelt/nyheder/uvm/2020/feb/200206-borne-ogundervisningsministeriet-offentliggor-evaluering-af-de-nationale-test

UVM (2020b). Ordblindetesten - en national ordblindetest. Lokaliseret den 12. marts 2020 på: https://www.uvm.dk/folkeskolen/laering-og-laeringsmiljoe/ specialundervisning/ordblindetesten

Vásquez, C., Brummans, B. \& Groleau, C. (2012). Notes from the field on organizational shadowing as framing. Qualitative Research in Organizations and Management: An International Journal, 7(2), 144-165. https://doi. org/10.1108/17465641211253075

Vygotsky, L. (1978). Mind in society: the development of higher psychological processes. Cambridge: Harvard University Press.

Young, V. M. \& Kim, D. H. (2010). Using assessments for instructional improvement: a literature review. Education Policy Analysis Archives, 18(19). DOI: https://doi.org/10.14507/epaa.v18n19.2010. 


\section{Learning Tech - Tidsskrift for læremidler, didaktik og teknologi Udgives af Læremiddel.dk}

Learning Tech er et forskningstidsskrift, hvor alle artikler er forskerbedømt i form af dobbeltblindt peer review. Tidsskriftet bringer artikler, der rammer genstandsfeltet mellem læremidler, didaktik og teknologi, og hensigten er at spille en betydelig rolle som platform for den voksende skandinaviske læremiddelforskning.

\section{Redaktion}

Stig Toke Gissel, UCL Erhvervsakademi og Professionshøjskole (ansvarshavende redaktør)

Bettina Buch, Professionshøjskolen Absalon

Hildegunn Juulsgaard Johannesen, University College Syd

Ove Christensen, Professionshøjskolen Absalon

René Boyer Christiansen, Professionshøjskolen Absalon

Thomas R.S. Albrechtsen, University College Syd

\section{Redaktionssekretær}

Trine Ellegaard, UCL Erhvervsakademi og Professionshøjskole

\section{Temaredaktion}

Stig Toke Gissel, UCL Erhvervsakademi og Professionshøjskole Thomas R.S. Albrechtsen, University College Syd

\section{Design og grafisk tilrettelæggelse}

Trefold - grafisk design og kommunikation

\section{Tryk}

Narayana Press, Gylling

ISSN 2445-7981 (Tryk)

ISSN 24.45-6810 (Online)

\section{Rettigheder}

(C) 2020 Læremiddel.dk og forfatterne

\section{Kontakt}

Læremiddel.dk, Niels Bohrs Allé 1, 5230 Odense M www.laeremiddel.dk

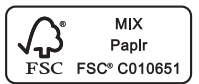

